OPEN ACCESS

Edited by:

Margarida Casadevall, University of Girona, Spain

Reviewed by:

Just T. Bayle-Sempere,

University of Alicante, Spain Gulnihal Ozbay,

Delaware State University, United States

*Correspondence: Vjekoslav Tičina ticina@izor.hr

Specialty section: This article was submitted to Marine Fisheries, Aquaculture and Living Resources, a section of the journal Frontiers in Marine Science

Received: 05 December 2019

Accepted: 19 March 2020

Published: 09 April 2020

Citation:

Tičina V, Katavić I and Grubišić L (2020) Marine Aquaculture Impacts on Marine Biota in Oligotrophic Environments of the Mediterranean

Sea - A Review.

Front. Mar. Sci. 7:217.

doi: 10.3389/fmars.2020.00217

\section{Marine Aquaculture Impacts on Marine Biota in Oligotrophic Environments of the Mediterranean Sea - A Review}

\author{
Vjekoslav Tičina ${ }^{1 *}$, Ivan Katavić2 ${ }^{2}$ and Leon Grubišić ${ }^{2}$ \\ 1 Laboratory of Fisheries Science and Management of Pelagic and Demersal Resources, Fishery Department, Institute \\ of Oceanography and Fisheries, Split, Croatia, ${ }^{2}$ Laboratory of Aquaculture, Fishery Department, Institute of Oceanography \\ and Fisheries, Split, Croatia
}

The potential impacts of marine aquaculture are reviewed, focusing both on smallscale local effects near the farm environment and a broad spatial scale that impacts a number of different ecosystem components. Local changes in productivity, biodiversity, and behavioral changes of wild fauna affected by nearby farm habitats were examined. Global aquaculture trends of growth perspectives as related to seafood supply, impacts on wild stock and biodiversity depletion, genetic changes in wild fish populations due to the escapement of cultured fish, capture-based aquaculture, and its potential impacts on marine habitats were discussed. Adopting integrated principles in planning aquaculture development and respecting the assimilative capacity of a potential farming zone may reduce negative consequences of the aquaculture industry on the marine ecosystem.

Keywords: farming, effects, ecosystem, oligotrophic, Mediterranean Sea

\section{INTRODUCTION}

Fish farming is an important food sector worldwide, providing a significant amount of seafood to the world's market, such as fish ( $>54$ million tonnes), molluscs ( $>17$ million tonnes), crustaceans and other products ( $\sim 8$ million tonnes) (FAO,, 2018). Such a trend makes aquaculture the fastest growing food production sector, with an annual growth rate of 5.8\% between 2001 and 2016. More fish from farming than from catch were observed in 37 counties. Fish are typically cultured in growth-out floating cages located in protected coastal areas. Since these sheltered locations usually have limited water exchange rates, their carrying capacities are often limited and consequently the local environment may be seriously affected through the release and accumulation of farm waste products (Pillay, 2004).

Marine aquaculture is also an important commercial activity in the Mediterranean Sea, including the Adriatic (Katavić, 2017). A particularly strong growth in recent years in the Adriatic - Ionian microregion is recognized. Such a development is contributing to satisfying the growing needs for sea-food market, and employment opportunities in islands and coastal areas.

Most farms are located in sheltered coastal marine ecosystems that are under pressure from numerous commercial users. Marine aquaculture is an integral part of growing coastal economy, and requires balancing the rights and responsibilities in using and preserving the marine ecosystem. However, due to low water exchange rates in these basins, there are concerns that growing 
human activities, including marine aquaculture with continuous waste discharge from numerous sites, might affect the water quality and marine habitats of a sensitive marine environment (Gabrielides et al., 1999).

Silvert (1992) assessed the environmental impacts of marine fish aquaculture and recognized that there are small scale local impacts at a specific farm affecting its immediate environment within $1 \mathrm{~km}$ radius (i.e., nearby habitats), and also certain regional impacts, affecting spatial scale of many kilometers on wild populations of marine biota as ecosystem components. Small scale impacts might be related to changes of the seabed biocenosis beneath aquaculture installations, local changes in productivity and biodiversity, behavioral changes of local wild fauna, etc. At the broad spatial scale, aquaculture impacts on marine biota might include genetic changes in wild fish populations due to cultured fish escapement, exploitation of wild populations in capture-based aquaculture, effects on threatened species, and changes in the behavior of the fisher communities as an integral part of marine ecosystems, etc.

The Adriatic basin, as the northernmost part of the Mediterranean basin is an important area for different aquaculture practices, such as shellfish aquaculture (mussels, clams, and oysters), finfish aquaculture (mainly seabass and seabream) and recently developed aquaculture activities related to capture-based bluefin tuna farming activities (Katavić, 2005; Katavić and Tičina, 2005). Despite the fact that the Adriatic Sea is often considered one of the most productive areas of the Mediterranean Sea, its eastern part with rocky coasts and very few small rivers represent an oligotrophic environment (Figure 1).

Effects of aquaculture on marine ecosystems have been studied within a large number of EU projects, particularly in the Mediterranean Sea area. These projects studied many different aquaculture's aspects, such as coastal, economic, and social sustainability (project: AQCESS), biofiltration (project: BIOFAQs), ecosystem approach for sustainability in aquaculture (project: ECASA), release of nutrients from fish farms on benthic vegetation in coastal ecosystem (project: MedVeg), development of modeling tools and guidelines for monitoring environmental effects (project: MERAMED), interactions between aquaculture and marine ecosystems (project: SAMI), etc. These projects have addressed a range of different issues related to interactions between aquaculture and the environment within the marine ecosystem (Karakassis, 2007). Two EU FP7 projects, AQUAMED and OrAQUA, paved the way for future development of aquaculture. These projects contributes to regulation on organic aquaculture, and mapped the needs of aquaculture stakeholders in the Mediterranean Sea respectively. Within framework of EU funded Horizon 2020 projects, AQUASPACE project dealt with ecosystem approach in making space for aquaculture (project: AQUASPACE), that is crucial for further aquaculture positioning in the Mediterranean coastal environment. Another one, MARIBE research and innovation project positioned aquaculture as one out of four emerging sectors aiming to support a blue economy. Future development is aiming to create a competitive, high-quality aquaculture sector that is economically sustainable and environmentally-friendly and socially responsible. Further step of aquaculture industry is dealing with innovation transfer network for Mediterranean mariculture (project: INTRANEMA), together with evaluation of potentials of new candidate fish species (DIVERSIFY project) opened further opportunity for expansion of marine aquaculture industry in the region.

Currently, some on-going EU projects such as ParaFishControl looking for better understanding of interactions between cultured fish and parasites aiming to develop innovative tools to prevent possible unwanted impacts on marine biota. AquaIMPACT is trying to use genetic technologies to provide nutritious and more growth-efficient fish, promoting at the same time practices of circular economy, better use of available natural resources and zero-waste practices in aquaculture.

There is large number of studies describing different impacts on marine environment caused by aquaculture practices in the Mediterranean Sea. Large number of them are reviewed (see Supplementary Table S1) with aim to get a wide comprehensive insight into aquaculture related impacts on marine biota. Therefore, overall goal of this paper is to provide a review of various aquaculture impacts on an oligotrophic marine environment at different spatial scales, with particular reference to the Mediterranean Sea including its northernmost part, the semi-enclosed and mostly shallow Adriatic basin, aiming to provide useful information for the policy makers, managers and various stakeholders.

\section{SMALL-SCALE SPATIAL (LOCAL) EFFECTS ON THE ECOSYSTEM}

\section{Impact on Nutrients}

Fish feed used in fish farming might serve as additional sources of nutrients. Organic loading is almost unavoidable due to the excess of uneaten feed and fish excretory products (Cromey et al., 2002). This is one of the most widely documented impacts of fish farms on the environment (Gowen et al., 1991; Wu, 1995; Fernandes et al., 2001). Organic waste originating from cultured fish settled on the seafloor is mineralized or accumulated in the sediments. Due to the combined effects of mineralization and resuspension, the sedimentation of organic waste particles on the seafloor near aquaculture installations results in carbon mineralization and nutrient regeneration (Valdemarsen et al., 2009).

The sedimentation of organic matter under the fish cage leads to reduced oxygen penetration and is reflected in stimulated mineralization rates. Accumulation of particulate waste near aquaculture cages can be several times higher than at unaffected sites, and declined rapidly with distance from the farm (Holmer et al., 2007; Kutti et al., 2007). More than $90 \%$ of the organic waste in marine sediments is closely associated with mineral surface (Keil et al., 1994). A portion of the organic matter preserved in marine sediment is decomposed into simple inorganic components and returned back to seawater. Depending on the composition of organic matter, its degradation rate is related to the rate of sedimentation, bioturbation and the amount of oxygen in bottom water and sediment (Keil et al., 1994).

Beside particulate organic waste, there are number of dissolved excretory products generated from fish farm. Ammonium is 


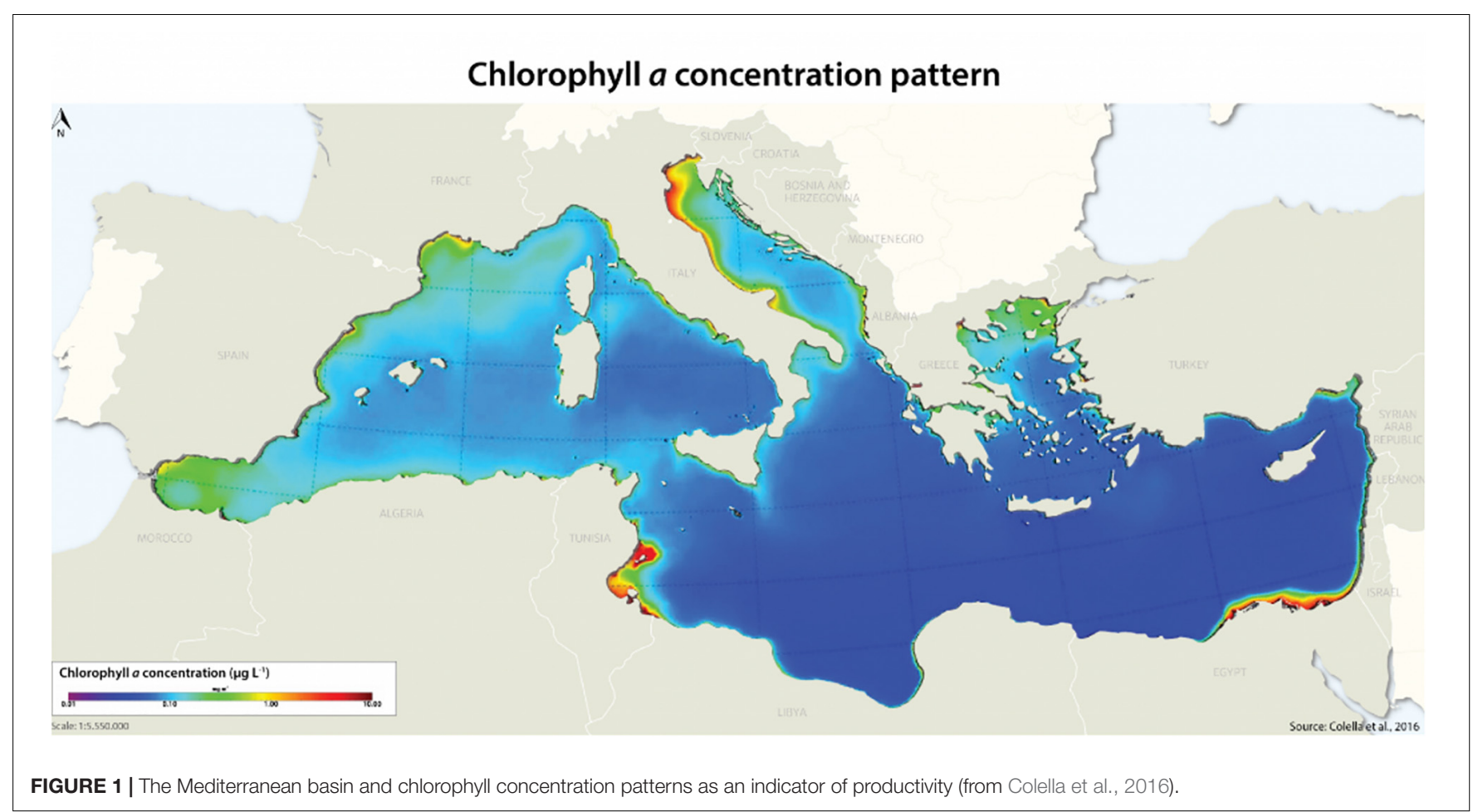

the main component among them. Elevated ammonium and nitrogen are common in sediments nearby fish farms (Holmer and Kristensen, 1992; Nickell et al., 2003). Dosdat (2001) explained the increase in the concentrations of ammonium and urea in areas close to the aquaculture sites, with the fact that both are direct products of fish excretion. In addition, sediments under fish farms are enriched with phosphorus (P). Holmer et al. (2007) suggested that $\mathrm{P}$ in the sediments can be used as an indicator of organic waste loading from farms.

Kušpilić et al. (2007) quantified dissolved and particulate matter from fish farms in the Adriatic stressing that nitrogen and phosphorus compounds are particularly important in the nutrient cycle (Table 1). Furthermore, effects on sediment have also been documented by several authors in the Mediterranean. These includes negative redox potential in the sediment (Hargrave et al., 1993; Pawar et al., 2001), accumulation of organic carbon and phosphorus (Matijević et al., 2006), various nitrogen compounds (Hall et al., 1990; Hargrave et al., 1997; Porello et al., 2005; Matijević et al., 2009, 2012), and changes in benthic habitats respectively (Karakassis et al., 1999, 2000, 2002; Mazzola et al., 1999; Kovać et al., 2001, 2004; La Rosa et al., 2001; Sarà et al., 2004).

The obtained values of organic carbon for cage farms along the eastern Adriatic coast are slightly higher than those obtained in the open Adriatic and coastal areas (Faganeli et al., 1994). Matijević et al. (2008) found slightly increased concentrations of inorganic nutrients in the water column impacted by the fish farm, in comparison with the control station. However, those concentrations were in the range with common values for the middle Adriatic area (Zore-Armanda et al., 1991). Studying cage aquaculture area in the middle Adriatic Sea, Skejić et al. (2011) noted that low phosphate concentrations may have implications for further nutrient uptake by phytoplankton. This may be explained with the phosphorus-limited nature of an oligotrophic environment (Krom et al., 1991, 2004). However, as suggested by Sanz-Lázaro and Marín (2008) the amount of organic matter, nutrients and other wastes released by fish farms in the marine environment should be limited.

\section{Fish Farming Impacts on the Biotic Marine Environment}

Fish farming impacts on the biotic component of the marine environment is the most evident in areas close to the rearing sites, and is more evident over the seabed than in the water column (Karakassis, 2001; Staglićić et al., 2017). In a pelagic environment, primary production, specifically chlorophyll was considered the most relevant biological variables for detecting eutrophic conditions. Since no excess nutrients were noted in the culturing area, Katavić and Antolić (1999) explained that

TABLE 1 | Discharge of nitrogen and phosphorus (tonnes/year) from fish farms (SB\&SB - seabass and seabream farming; BFT - bluefin tuna farming) in the Croatian waters of the Adriatic Sea (Kušpilić et al., 2007).

\begin{tabular}{lccc}
\hline Parameter & SB\&SB & BFT & Total \\
\hline Dissolved nitrogen & 364 & 975 & 1,339 \\
Particulate nitrogen & 28.65 & 27 & 55.65 \\
Total nitrogen & 392.65 & 1,002 & 1394.65 \\
Dissolved phosphorus & 35.7 & 20 & 55.7 \\
Particulate phosphorus & 15 & 1.1 & 16.1 \\
Total phosphorus & 50.7 & 21.1 & 71.8
\end{tabular}


strong currents might influence fast dispersion and dilution of nutrients, and phytoplankton organisms were not able to benefit from released nutrients.

As intensity of fish feeding is highly influenced by the sea-water temperatures, that in turn may increase in primary production nearby fish farms in an oligotrophic environment (Pitta et al., 1999). A similar case was found in the eastern Adriatic where an increase in phytoplankton biomass and primary production during the summer were occurred. This can be explained by low water exchange in certain farming zone, and consequently phytoplankton organisms might be able to uptake the nutrients released from the farm, that in turn may contribute to the increase in primary productivity and biomass (Skejić et al., 2011). The dominance of autotrophic microflagellates in the phytoplankton community supports the conclusions of Pitta et al. (2005), who verified the general dominance of small autotrophic and heterotrophic organisms. However, the increase in phytoplankton biomass caused by fish farming was not reflected in the appearance of a toxic algal bloom, neither in the eastern Mediterranean (Machias et al., 2004) nor eastern Adriatic (Skejić et al., 2011).

In oligotrophic ecosystems, nutrient inputs may be beneficial for marine biota as it sustains higher level of production by phytoplankton and possibly zooplankton communities. Several authors have described the impact of aquaculture on phytoplankton assemblages in the Mediterranean Sea (Pitta et al., 1999; Díaz et al., 2001; Karakassis et al., 2001; La Rosa et al., 2002), finding no significant differences in species composition of phytoplankton assemblages between aquaculture sites and control locations.

Despite potential beneficial effects at the wider ecosystem scale, local ecosystem disturbances are possible. High local input of nutrients could result in the excessive growth of certain organisms. Negative influences of fish farming on structure of benthic assemblages have been reported in the middle Adriatic region (Katavić and Antolić, 1999). They found the sediment highly enriched with organic matter and consequently the abundance of macroflora was dominated by nitrophilic components, with low macrofauna species diversity. Nitrophilic algae of the genera Enteromorpha, Ulva, and Cladophora were found in the tidal zone (mediolittoral) at the nearest coastline, and accompanying floating objects due to their tolerance to high nutrient concentrations. The main composition elements of the native stratified biocenosis layers (i.e., algae from genus Cystoseira) inhabiting rocky habitats on the farm sites could partially or completely disappear. These new ecological conditions could favor the sudden development of certain organisms (diatoms, filamentous brown algae, Acinetospora sp.) which could cover the sea bed and existing benthic biocenosis (Kušpilić et al., 2007). They noted that finfish (i.e., seabass and seabream) and bluefin tuna farming locally altered several ecological parameters that have an effect on the seabed, and consequently change the composition and distribution of the benthic community near aquaculture installations (Mirto et al., 2002). Increased fine particle sedimentation changes the texture of the seabed (i.e., mudding). Fine particles that settle on sediment and sessile benthic organisms might have a negative effect, such as reducing or eliminating the native benthic biocenoses (epilithe, epiphyte, epizooties), and thus resulting in reduced biodiversity of the local environment.

If aquaculture facilities are located in shallow, closed, or semiclosed areas with insufficient water exchange than increased sedimentation of organic matter over a relatively small surface will likely create hypoxic/anoxic conditions. This situation is primarily indicated by development of the bacteria Begiatoa $s p$. that destroys the locally existing biocenosis. A particularly important native community for biodiversity and repopulation of the marine ecosystem is the seagrass Posidonia oceanica, which serves as a nursery ground for many fish species to sustain the high biodiversity of the marine ecosystem. Largescale degradations of this very sensitive phanerogams due to the aquaculture activities are reported (Delgado et al., 1999; Ruiz et al., 2001). The decline or disappearance of $P$. oceanica meadows close to aquaculture installations has been attributed primarily to sedimentation and light penetration (Holmer et al., 2007). If located over or near seagrass, marine aquaculture installations (floating cages) might have an adverse local effect on this important ecosystem component.

\section{Wild Fish Aggregations Around Marine Fish Farms}

Possible impacts of aquaculture on marine biota at higher trophic levels (i.e., different groups of vertebrates) in the past have been much less studied (i.e., Machias et al., 2004, 2005; Vita et al., 2004), as compared to the impact on previously described marine biota from lower trophic levels. Since finfish farms act as feeding and breeding grounds for several fish species, fish are also attracted by additional structures providing protection and favorable habitats. Though they use the entire farming area as habitat, wild fish populations were most abundant in the bottom layers, concentrated below the cage, and abundance declined significantly with increasing distance from the breeding area (Šegvić-Bubić et al., 2011b). Authors noticed that in some cases the average number of fish individuals can be 40 times higher near the fish farm, than in control locations (unpublished field studies). In spite of permanent export of organic waste from the fish farms, the presence of wild fish communities obviously mitigates or prevent the potentially negative impacts of the aquaculture activities (Vita et al., 2004; Bayle-Sempere et al., 2013).

Recent studies have confirmed that aggregated wild fish can remove up to $25 \%$ of particulate wastes originated from fish farm, depending on the biomass and structure of wild fish communities around the cages (Ballester-Moltó et al., 2017). Certainly, the highly dynamic physical environment of fish farms, with respect to the rapid utilization of nutrients by phytoplankton and consumption of food remains by wild fish, consequently reduces the negative impact of organic waste on the sediment and seabed biocenosis.

Staglićić et al. (2017) noted that one third of all wild fish recorded around aquaculture cages were juvenils, and the majority belonged to the family Sparidae. Some authors reported a high abundance of juveniles around finfish farms in 
the southwestern Mediterranean (Fernández-Jover et al., 2009). Obviously, farming installations provide shelter for young fish, creating specific ecological niches, and thus reducing the risk of predation. Juveniles from the Sparidae family appear to have a strong preference for gathering nearby bluefin tuna (BFT) floating cages (Šegvić-Bubić et al., 2011b). Staglićić et al. (2017) described the ecological effects of BFT breading related to associated wild fish assemblages near cages. They concluded that fish farms could be regarded as unique, small, marine protected areas.

The association between wild fish development stages with floating objects has long been understood and used for fishing purposes (Fréon and Dagorn, 2000). In addition, Dempster and Taquet (2004) recognized that many marine species are attracted in significant numbers to floating structures, which have been coined fish aggregated devices (FAD). Aquaculture facilities display a FAD effect by providing an additional food source for wild fish near cages (Sánchez-Jerez et al., 2007; Bacher et al., 2012). Several studies have examined the changes occurred in native assemblages of wild fish following the setting of farming installations in an oligotrophic marine ecosystem. According to Dempster et al. (2002), wild fish gathering within aquaculture zones are mostly large adults with good body condition, since the steady food supply from cages enables good spawning success of these fish. Conclusion of many authors is that the release of nutrients from aquaculture facilities attracts local populations and resulted in changed fish species composition, and higher abundances (Machias et al., 2004; Fernández-Jover et al., 2007, 2008; Šegvić-Bubić et al., 2011b; Arechavala-López et al., 2013a; Bacher et al., 2015). Therefore, the impacts of aquaculture could be highly positive on the marine ecosystem, and might substantially increase resilience to overfishing of native populations targeted by local fishing communities.

As expected, considerable increase of fish aggregation has been documented near aquaculture sites all along the Mediterranean coastline (Valle et al., 2007). This imply that there might be a very efficient transfer of various nutrients up the food web (Machias et al., 2004). Under abundant food supply, wild fish aggregations near fish farms persist all year-round, without detectable seasonal differences (Staglićić et al., 2017).

Many fish species have a flexible feeding behavior (Dill, 1983). Therefore, aquaculture installations act as new and rich feeding areas (i.e., via excess feed), resulting in shifts in their natural feeding behavior (Tuya et al., 2006). FernándezJover et al. (2007) analyzed the nutrition of horse mackerel (Thachurus mediterraneus) aggregated near fish cages in Spain and noted that pelleted feed was the main food component in their stomachs, while the natural diet consists primarily of juvenile fish, small crustaceans and cephalopods. As noted by Bayle-Sempere et al. (2013), pellets consumed by wild fish gathered around farming cages represent an additional energy input in the ecosystem, having possible impact on system trophic structure. In these situations, wild fish around cages act as ecosystem buffer for additional energy flows into the system. Floating cages in the southwestern Mediterranean also attracts large numbers of other fish species, such as bogue (Boops boops) and saddled bream - oblada (Oblada melanura) juveniles (Fernández-Jover et al., 2009), and therefore serve as artificial nursery grounds. It is likely that these juveniles inhabiting aquaculture areas will have a positive effect on native population's recruitment.

Taking into account high concentration of wild and farmed fish, aquaculture areas may also attract predator species from the highest trophic levels. Bottlenose dolphins (Tursiops truncatus) often gather in the vicinity of fish farms along the Italian coast (Díaz-López and Bernal-Shirai, 2007). Several authors have also reported that the dense assemblages of small wild fish congregating around aquaculture facilities attracted large predatory fish species, such as bluefin tuna (Thunnus thynnus), bluefish (Pomatomus saltatrix), common dentex (Dentex dentex), dolphinfish (Coryphaena hippurus), greater amberjack (Seriola dumerili), and others (Dempster et al., 2002; Šegvić-Bubić et al., 2011b; Arechavala-López et al., 2015). Güçlüsoy and Savas (2003) reported that even monk seals (Monachus monachus) have been reported to hunt for fish at fish farms in the Aegean Sea on the Turkish coast, that eventually resulted in damage of cage's nets and consequently a large number of escapees.

Since aquaculture concessional areas with rearing installations are no-fishing zones, they effectively function as "no-take zones." In general, the FAD effect of aquaculture installations can be considered as a positive impact of aquaculture on marine biota in an oligotrophic ecosystem.

\section{Effects of Shellfish Aquaculture}

Among marine bivalve molluscs only two species, the mussel (Mytilus gallopronvicialis) and the clam (Ruditapes philippinarum) are produced in a massive scale in the Mediterranean Sea. The production of oysters remains at limited or semi-experimental dimension. The other shellfish species come entirely from natural fishing but between those, some present characteristics suitable for aquaculture (Katavić, 2017).

There are very few studies on the effects on marine organisms caused by shellfish aquaculture. It has the ability to affect the surrounding environment in both positive and negative ways. On the one side farming of filter-feeding marine organisms is considered as the most ecologically acceptable aquaculture activities. On the other hand, shellfish farming may influence primary and secondary productivity, and thus have impact on water column and sediment infauna. Furthermore, having shellfish farming in natural environments, it may create conflicts with other coastal users, such as nature conservation, recreation, tourism, and related activities (Gallardi, 2014).

Based on the fact that cultured shellfish are active filter feeders, Neori et al. (2004) suggested integration of shellfish into finfish farming, creating an integrated multi-trophic aquaculture (IMTA), aiming to improve economic viability and to reduce local eutrophication caused by fish feeding. However, it should be kept in mind that such IMTA practice is likely to cause problems with more intensive cage's nets bio-fouling, which in turn may cause numerous unwanted effects such as needs of variety of toxic anti-fouling substances, increased operative/maintenance in terms of man power and energy costs. Currently, research efforts are directed to test IMTA practice in different regions (EU project IMPAQT), including the Mediterranean Sea. 
Despite the fact that aquaculture of autochthonous shellfish species might be an ecologically sustainable activity with very little or no negative impacts on marine environment, the interaction of culturing organisms with native ones is almost impossible to control. In the past, shellfish farmers were looking for new species to be introduced in shellfish farming, and it caused spreading distribution area of the pacific oyster (Magallana gigas) throughout the world oceans. This shellfish species was transferred from Japan to US and Canada pacific coast during 1950s. In this new area, M. gigas was naturalized and from there it was imported to France in the 1970s where breeding populations of pacific oyster was established (Gosling, 2003). Currently, this species represents serious threat to autochthonous native oyster populations in the Adriatic Sea (Ezgeta-Balić et al., 2019).

A similar situation happened with aquaculture of the Manila clam (Ruditapes philippinarum). In some countries on the Mediterranean coast, where $R$. philippinarum has been introduced as new species in aquaculture, it seems to be more successful in competition with local clam species. This is well documented in the area of Italian lagoons in the Adriatic (Mantovani et al., 2006), where it spreads and reduce population of the native clam, Ruditapes decussatus.

There is also permanent risk that shellfish diseases can be transferred from cultured organisms to wild animals without their physical contact with subsequent detrimental effects to wild populations. In some cases, transmission of shellfish's pathogens may occur during transfer of shellfish between different culture sites, e.g., transmission of parasite Bonamia ostreae to the flat oyster Ostrea edulis in the most of the Mediterranean area. Transmission of the pathogen Bonamia ostrea can occur from oyster to oyster, via the water column (Culloty et al., 1999).

Šegvić-Bubić et al. (2011a) observed that shellfish breeding installations along the eastern Adriatic coast may act as FAD and attract wild marine organisms. Over the past decade, shellfish farmers throughout the Mediterranean area have reported damages caused by predation of wild marine organisms on shellfish cultures (oysters and mussels). Most of these damages are supposedly caused by seabream, though further research on these impacts are needed.

\section{WIDE-SCALE SPATIAL EFFECTS ON THE ECOSYSTEM}

Cultured seafood can relieve fishing pressure and enhance depleted wild stocks, thus providing certain positive impacts on biodiversity (Diana, 2009). In addition, capture-based aquaculture (i.e., BFT rearing) also generates a considerable amount of "new" fish biomass, which is able to satisfy a greater market demand than fisheries alone, but with no additional increases in fishing mortality and it can be considered to have positive impact on ecosystem (Kušpilić et al., 2007). Bostock et al. (2016) recognized the global trends indicating future growth of marine aquaculture in the Mediterranean Sea, suggesting that quantities of aquaculture production are likely to increase by $55 \%$ up to 2030, focusing mostly on finfish species such as seabass
(Dicentrarchus labrax) and gilthead seabream (Sparus aurata). Karakassis et al. (2005) estimated that with an aquaculture production of finfish up to 150,000 tons/year, contribution of nutrients ( $\mathrm{N}$ and $\mathrm{P}$ ) from aquaculture activities represent less than $5 \%$ of total discharges from other anthropogenic sources in the Mediterranean ecosystem. Having such a predicted aquaculture development it is expected that future marine aquaculture impact could be more pronounced.

\section{Escapees - Interactions With Native Populations and Genetic Impacts}

One of the wide-scale impacts of aquaculture on marine biota relates to the escapement of cultured specimens and their genetic interactions with wild populations (Dempster et al., 2002). Somarakis et al. (2013) studied the spontaneous production of fertilized eggs from gilthead sea bream (Sparus aurata) reared in floating cages in Greece, their survival and dispersal in the open waters. Approximately twofold increase of the wild seabream population within area of the Messolonghi Lagoon were reported. This phenomenon might be linked with an increased size of caged seabream as to meet novel market requirements. Therefore, possible spontaneous spawning of gilthead seabream within cages is supposed to have led to additional recruitment (Dimitriou et al., 2007). More recently, Žužul et al. (2019) noted that $15 \%$ of gilthead seabream in the Adriatic Sea are the result of spawning between escapees and specimens from native populations. Genetic mapping of this hybrids (Šegvić-Bubić et al., 2017) can be seen as a first step toward developing a strategy for mitigation of impact related to fish escapees aimed at controlling further erosion of genetic integrity.

Technical and operational failures of fish farming technology, such as storm damage or wear and tear of nets, are the main risks that may result in escapees. Aquaculture escapees may also be possible vectors for disease or parasite transmission to other species in the ecosystem (Arechavala-López et al., 2013b). As emphasized by Dempster et al. (2005) and Valle et al. (2007), they represent a high risk and cause potentially negative impact of farmed fish to wild fish populations. Escapees may cause unwanted ecological effects to native fish populations due to predation and competition with native marine organisms. This issue was in the focus of the EU research project PREVENT ESCAPE, considering escapees as serious threat to ecosystem biodiversity in Europe's marine waters. However, it should be noted that this threat is not related to escapees from capturebased aquaculture, such as BFT aquaculture.

\section{Interaction of Capture-Based Bluefin Tuna Aquaculture With Natural Ecosystem}

Tuna aquaculture, in comparison with other aquaculture activities, is the most recently developed aquaculture activity. According Miyake et al. (2003) bluefin tuna (BFT) aquaculture, based on trap fishery, commenced in Canada in late 1960s and in the Mediterranean Sea in the late 1970s, while the Australian tuna farming in the 1980s was based on purse seine fishery. This can be considered capture-based aquaculture, based on tuna 
fishery targeting natural tuna populations. Recently, tunas are caught using purse seine fishing gear, and transferred alive to floating cages for rearing purposes. Two different practices - tuna fattening and tuna farming - can be distinguished based on the duration (fattening of several months; farming of more than 1 year) and sizes of initial seed fish (fattening - large seed fish; farming - small seed fish). The common aim of both practices is to increase the commercial value of tunas used as seed fish, by increasing their size and fat content, with intensive feeding in the cages using small pelagic fish as feed. In the oligotrophic eastern Adriatic Sea, BFT aquaculture is based exclusively on farming procedures.

This form of aquaculture activity has a range of both positive and negative impacts on marine biota within the ecosystem. Grubišić et al. (2013) reported spontaneous spawning of bluefin tuna (Thunnus thynnus) during rearing practices within cages, which could possibly increase the abundance of juvenile tunas in the open sea (Džoić et al., 2017), and have a positive effect on the resilience of this species to intensive fishery exploitation.

In the case of BFT aquaculture, it was observed that many fishing vessels engaged in bottom trawling fishery, ceased their fishing activities and switch to aquaculture servicing activities (Katavić et al., 2003). Changes in activity of those ex-fishing vessels consequently contributed to decrease of fishing mortality in the over-exploited demersal fish stocks in the Mediterranean. As Katavić and Tičina (2005) noted, 30 fishing vessels previously operating as bottom trawlers in Croatia, become fully integrated into tuna farming operations, thus reducing fishing pressure on native Adriatic stocks. Therefore, in this sense BFT aquaculture may have indirect positive effects on demersal fish stocks. On the other hand, this activity created new market demand for small pelagic fish used as feed for tunas in cages, leading to increased exploitation of small pelagic fish resources from the marine ecosystem.

BFT aquaculture also has indirect impacts on threatened marine biota. A number of large pelagic shark species, turtles and marine mammals in the Mediterranean Sea are listed in Red Book of Threatened Species (Abdul Malak et al., 2011; IUCN,, 2012). These species, appearing as by-catch in pelagic fisheries, are usually most affected by large pelagic driftnets and pelagic longlines targeting tunas and swordfish (Tudela, 2004). To a lesser extent, endangered species are caught by purseseine fisheries, and may possibly be released alive. Consequently, changes in fishing gears (i.e., changes of pelagic driftnets and longlines to purse-seines) motivated by BFT aquaculture demand for live seed fish, eventually used in tuna fattening and farming activities, probably also have an indirect beneficial impact on threatened species conservation, and therefore on conservation of marine ecosystem biodiversity at the highest trophic levels.

BFT feeding in grow-out cages represent an additional food source for seabirds. The indirect effect on seabirds may be considered a perturbation in their usual food supplies and eventually leads to major changes in inter-specific relationships and trophic parameters in the surrounding environment. However, it is very difficult to quantify the impact on seabird's populations caused by food supply from aquaculture facilities, since there is no clear idea as to the positive or negative effects at the ecosystem level (Tudela, 2004).

Aquaculture sitting is competing for space with other marine ecosystem users (i.e., tourism, marine traffic, etc.) and may provoke conflicts and water quality deterioration, particularly if aquaculture activities is not properly planned and managed. Selecting suitable sites in terms of the biophysical environment and defining the carrying capacity is of great importance for the sustainability of an aquaculture operation. There is a need to avoid conditions that might induce stress, decrease growth rates or predispose occurrence of fish diseases. Therefore, one of the main criteria in the site selection process is to avoid polluted areas with low water exchange (Katavić and Dadić, 2000). Furthermore, aquaculture activities need to be developed in the context of an ecosystem approach, in harmony with other sectors, policies and goals. Geographic Information Systems (GIS) in combination with multi-criteria analysis could be used as a flexible and transparent decision support system for evaluating potential aquaculture sites (Katavić et al., 2017).

\section{CONCLUSION}

Aquaculture is recognized as an important food production sector that contributes to the global economy, food safety and more specifically to rural development in the coastal areas where employment opportunities are often limited (i.e., islands). For the aquaculture industry to expand, the environmental impacts need to be properly addressed.

Accumulation of particulate waste near aquaculture cages was found to be much higher than at distant control's sites, though this declined very quickly with increasing distance from the farming cages. Organic matter originated from fish waste settled on the seafloor is mineralized or accumulated in the sediment. A part of the organic matter stored in the seabed sediment is decomposed into simple inorganic components and returned back to seawater. However, increases in nutrient discharge may be detrimental when the respective farming area is not flushed out and the calculated assimilative capacity of the receiving water is exceeded. In the long run, high nutrient concentrations in sensitive areas might have severe effects on species richness and biodiversity of oligotrophic environments, particularly those harboring endemic species.

Impacts on nutrient contents and consequent productivity may result in certain positive effects, such as increased fish production. Due to abundant food supply, wild fish aggregations near caged farms persist year-round. Fish are also attracted by additional structures (FAD effect) providing protection and numerous favorable habitats for juveniles. Wild fish populations were most abundant in the bottom layers, concentrated below the cage, with numbers of fish declining significantly with increasing distance from the breeding area. Therefore, this impact of aquaculture on the marine ecosystem can be considered positive as it enables adults to be in good condition for future spawning, while also providing an artificial nursery ground for juveniles inhabiting areas within aquaculture installations. 
Cultured shellfish species are active filter-feeders, and they are rearing without any additional input in the marine ecosystem, and may have a crucial role in future development of integrated multi-trophic aquaculture practices. However, since the interaction of culturing organisms with native ones is almost impossible to fully control, any cultivation of allochthonous shellfish and fish species might have an undesirable impact on native autochthonous populations and biodiversity.

Finfish and BFT farming in floating cages are the most common type of aquaculture in the Mediterranean Sea. It obviously has many different impacts on marine biota in the ecosystem, but the most studied are local impacts on flora and fauna nearby aquaculture installations. Considering the fact that each fish farm represents additional nutrient/energy input into ecosystem, the role of wild marine biota aggregated around farming sites, acting as "buffers" are very important in preventing local degradation of the environment.

Escaped farmed fish may represent a vector for the spread of disease among wild fish populations. Escapement of cultured specimens and their genetic interactions with wild populations represent a high risk and threat to natural ecosystem biodiversity. However, this is not the case with escapees from capturebased aquaculture, such as BFT aquaculture. Indirect impact of BFT aquaculture on endangered large pelagic species can be considered as beneficial, but it pose greater risk on overexploitation of small pelagic fish stocks.

Well-balanced and properly managed marine aquaculture operations should not significantly alter the surrounding environment. Identification of potentially suitable areas for aquaculture should be based on an integrated approach that considers the ecological, technological, economic and socio-cultural impacts of different locations. Such a practice, which is too often overlooked, might otherwise

\section{REFERENCES}

Abdul Malak, D., Livingstone, S. R., Pollard, D., Polidoro, B. A., Cuttelod, A., Bariche, M., et al. (2011). Overview of the Conservation Status of the Marine Fishes of the Mediterranean Sea. Gland: IUCN.

Arechavala-López, P., Borg, J. A., Šegvić-Bubić, T., Tomassetti, P., Özgül, A., and Sánchez-Jerez, P. (2015). Aggregations of wild Atlantic bluefin tuna (Thunnus thynnus L.) at Mediterranean offshore fish farm sites: environmental and management considerations. Fish. Res. 164, 178-184. doi: 10.1016/j.fishres. 2014.11.011

Arechavala-López, P., Fernández-Jover, D., Black, K. D., La Doukakis, E., BayleSempere, J. T., Sánchez-Jerez, P., et al. (2013a). Differentiating the wild or farmed origin of Mediterranean fish: a review of tools for sea bream and sea bass. Rev. Aquac. 5, 137-157. doi: 10.1111/raq.12006

Arechavala-López, P., Sánchez-Jerez, P., Bayle-Sempere, J. T., Uglem, I., and Mladineo, I. (2013b). Reared fish, farmed escapees and wild fish stocks: a triangle of pathogen transmission of concern to Mediterranean aquaculture management. Aquac. Environ. Interact. 3, 153-161. doi: 10.3354/aei00060

Bacher, K., Gordoa, A., and Sagué, O. (2012). Spatial and temporal extension of wild fish aggregations at Sparus aurata and Thunnus thynnus farms in the north -western Mediterranean. Aquac. Environ. Interact. 2, 239-252. doi: 10.3354/ aei00042

Bacher, K., Gordoa, A., and Sagué, O. (2015). Feeding activity strongly affects the variability of wild fish aggregations within fish farms: a sea bream farm as a case study. Aquac. Res. 46, 552-564. doi: 10.1111/are. 12199 cause environmental pressures and create conflicts among competing users.

\section{AUTHOR CONTRIBUTIONS}

All authors contributed equally in the preparation of this review article.

\section{FUNDING}

This manuscript was funded by Ministry of Science and Education of the Republic of Croatia within the framework of projects "Biodiversity and management of pelagic and demersal resources of the Adriatic Sea" (Grant No. 001-0013077-0532) and "Zootechnical and environmental aspects of fish and cephalopods culture" (Grant No. 001-0010501-0560).

\section{ACKNOWLEDGMENTS}

This work was aided by Institute of Oceanography and Fisheries, and supported by the Ministry of Science and Education of Republic of Croatia. We are grateful to reviewers and their useful comments to improve this manuscript.

\section{SUPPLEMENTARY MATERIAL}

The Supplementary Material for this article can be found online at: https://www.frontiersin.org/articles/10.3389/fmars. 2020.00217/full\#supplementary-material

Ballester-Moltó, M., Sánchez-Jerez, P., and Aguado-Giménez, F. (2017). Consumption of particulate wastes derived from cage fish farming by aggregated wild fish. An experimental approach. Mar. Environ. Res. 130, 166-173. doi: 10.1016/j.marenvres.2017.07.014

Bayle-Sempere, J. T., Arreguin-Sánchez, F., Sánchez-Jerez, P., Salcido-Guevara, L. A., Fernández-Jover, D., and Zetina-Rejon, M. J. (2013). Trophic structure and energy fluxes around a mediterranean fish farm. Ecol. Model. 248, 135-147. doi: 10.1016/j.ecolmodel.2012.08.028

Bostock, J., Lane, A., Hough, C., and Yamamoto, K. (2016). An assessment of the economic contribution of EU aquaculture production and the influence of policies for its sustainable development. Aquac. Int. 24, 699-733. doi: 10.1007/ s10499-016-9992-1

Colella, S., Falcini, F., Rinaldi, E., Sammartino, M., and Santoleri, R. (2016). Mediterranean ocean colour chlorophyll trends. PLoS One 11:e0155756. doi: 10.1371/journal.pone.0155756

Cromey, C. J., Nickell, T. D., and Black, K. D. (2002). DEPOMOD-modelling the deposition and biological effects of waste solids from marine cage farms. Aquaculture 214, 211-239. doi: 10.1016/s0044-8486(02)00368-x

Culloty, S. C., Novoa, B., Pernas, M., Longshaw, M., Mulcahy, M. F., Feist, S. W., et al. (1999). Susceptibility of a number of bivalve species to the protozoan parasite Bonamia ostreae and their ability to act as vectors for this parasite. Dis. Aquat. Organ. 37, 73-80. doi: 10.3354/dao037073

Delgado, O., Ruiz, J., Pérez, M., Romero, J., and Ballesteros, E. (1999). Effects of fish farming on seagrass (Posidonia oceanica) in a Mediterranean bay: seagrass decline after organic loading cessation. Oceanol. Acta 22, 109-117. doi: 10.1016/ s0399-1784(99)80037-1 
Dempster, T., Fernández-Jover, D., Sánchez-Jerez, P., Tuya, F., Bayle-Sempere, J., Boyra, A., et al. (2005). Vertical variability of wild fish assemblages around seacage fish farms: implications for management. Mar. Ecol. Prog. Ser. 304, 15-29. doi: 10.3354/meps304015

Dempster, T., Sánchez-Jerez, P., Bayle-Sempere, J. T., Gimenez-Casalduero, F., and Valle, C. (2002). Attraction of wild fish to sea cage fish farms in the southwestern Mediterranean Sea: spatial and short-term temporal variability. Mar. Ecol. Prog. Ser. 242, 237-252. doi: 10.3354/meps242237

Dempster, T., and Taquet, M. (2004). Fish aggregation device (FAD) research: gaps in current knowledge and future directions for ecological studies. Rev. Fish. Biol. Fish. 14, 21-42. doi: 10.1007/s11160-004-3151-x

Diana, J. S. (2009). Aquaculture production and biodiversity conservation. Bioscience 6, 27-39. doi: 10.1525/bio.2009.59.1.7

Díaz, M. M., Temporetti, P. T., and Pedrozo, L. F. (2001). Response of phytoplankton to enrichment from cage fish waste in Alicura Reservoir (Patagonia, Argentina). Lake Reserv. Manage. 6, 151-156.

Díaz-López, B., and Bernal-Shirai, J. A. (2007). Bottlenose dolphin (Tursiops truncatus) presence and incidental capture in a marine fish farm on the northeastern coast of Sardinia (Italy). J. Mar. Biol. Ass. U.K. Spec. Issue 87, 113-117. doi: 10.1017/S0025315407054215

Dill, L. M. (1983). Adaptive flexibility in the foraging behavior of fishes. Can. J. Fish. Aquat. Sci. 40, 398-408. doi: 10.1139/f83-058

Dimitriou, E., Katselis, G., Moutopoulos, D. K., Akovitiotis, C., and Koutsikopoulos, C. (2007). Possible influence of reared gilthead sea bream (Sparus aurata, L.) on wild stocks in the area of the Messolonghi lagoon (Ionian Sea, Greece). Aquac. Res. 38, 398-408. doi: 10.1111/j.1365-2109.2007.01681.x

Dosdat, A. (2001). "Environmental impact of aquaculture in the Mediterranean: nutritional and feeding aspects," in Environmental Impact Assessment of Mediterranean aquaculture Farms, eds A. Uriarte, and B. Basurco, (Zaragoza: CIHEAM), 23-36.

Džoić, T., Beg Paklar, G., Grbec, B., Ivatek Šahdan, S., Zorica, B., Šegvić Bubić, T., et al. (2017). Spillover of the Atlantic bluefin tuna offspring from cages in the Adriatic Sea: a multidisciplinary approach and assessment. PLoS One 12:e0188956. doi: 10.1371/journal.pone.0188956

Ezgeta-Balić, D., Šegvić-Bubić, T., Staglićić, N., Lin, Y., Bojanić Varezić, D., Grubišić, L., et al. (2019). Distribution of non-native Pacific oyster Magallana gigas (Thunberg, 1793) along the eastern Adriatic coast. Acta Adriat. 60, 137-146.

Faganeli, J., Pezć, J., Ogorelec, B., Mišić, M., and Najdek, M. (1994). The origin of sedimentary organic matter in the Adriatic. Cont. Shelf Res. 14, 365-384. doi: 10.1016/0278-4343(94)90024-8

FAO, (2018). The State of World Fisheries and Aquaculture 2018 - Meeting the Sustainable Development Goals. Rome: FAO.

Fernandes, T. F., Eleftheriou, A., Ackefors, H., Eleftheriou, M., Ervik, A., SánchezMata, A., et al. (2001). The scientific principles underlying the monitoring of the environmental impacts of aquaculture. J. Appl. Ichthyol. 17, 181-193. doi: 10.1046/j.1439-0426.2001.00315.x

Fernández-Jover, D., López-Jimenez, J. A., Sánchez-Jerez, P., Bayle-Sempere, J., Gimenez-Casalduero, F., Martinez-López, F. J., et al. (2007). Changes in body condition and fatty acid composition of wild Mediterranean horse mackerel (Trachurus mediterraneus, Steindachner, 1868) associated with sea cage fish farms. Mar. Environ. Res. 63, 1-18. doi: 10.1016/j.marenvres.2006.05.002

Fernández-Jover, D., Sánchez-Jerez, P., Bayle-Sempere, J. T., Arechavala-López, P., Martinez-Rubio, L., López Jimenez, J., et al. (2009). Coastal fish farms are settlement sites for juvenile fish. Mar. Environ. Res. 68, 89-96. doi: 10.1016/j. marenvres.2009.04.006

Fernández-Jover, D., Sánchez-Jerez, P., Bayle-Sempere, J. T., Valle, C., and Dempster, T. (2008). Seasonal patterns and diets of wild fish assemblages associated with Mediterranean coastal fish farms. ICES J. Mar. Sci. 65, 11531160. doi: 10.1093/icesjms/fsn091

Fréon, P., and Dagorn, L. (2000). Review of fish associative behavior: toward a generalization of the meeting point hypothesis. Rev. Fish. Biol. Fish. 10, 183-207.

Gabrielides, G. P., Henogre, Y., Kamizoulis, G., Coton, E., Ceecarelli, R., Triolo, L., et al. (1999). "Human activities and pressures," in , State and Pressures of the Marine and Coastal Mediterranean Environment, Vol. 5, eds G. Izzo, and S. Moretti, 47-75.
Gallardi, D. (2014). Effects of bivalve aquaculture on the environment and their possible mitigation: a review. Fish Aquac. J. 5, 105.

Gosling, E. M. (2003). Bivalve Molluscs: Biology, Ecology and Culture. Fishing News Books. Hoboken, NJ: Wiley-Blackwell, 443.

Gowen, R. J., Weston, D. P., and Ervik, A. (1991). "Aquaculture and the benthic environment: a review," in Proceedings of the 1st International Symposium on Nutritional Strategies in Management, Nutritional Strategies and Aquaculture Waste, eds C. B. Cowey, and C. Y. Cho, (Guelph: University of Guelph), 187-205.

Grubišić, L., Šegvić-Bubić, T., Lepen Pleić, I., Mišlov-Jelavić, K., Tičina, V., Katavić, I., et al. (2013). Morphological and genetic identification of spontaneously spawned larvae of captive bluefin tuna in the Adriatic Sea. Fisheries 38, 410-417. doi: 10.1080/03632415.2013.826201

Güçlüsoy, H., and Savas, Y. (2003). Interaction between monk seals Monachus monachus (Hermann, 1779) and marine fish farms in the Turkish Aegean and management of the problem. Aqua. Res. 9, 777-783. doi: 10.1046/j.1365-2109. 2003.00884.x

Hall, P. O. J., Anderson, L. G., Holby, O., Kollberg, S., and Samuelsson, M. O. (1990). Chemical fluxes and mass balances in a marine fish cage far. I. Carbon. Mar. Ecol. Prog. Ser. 61, 61-73. doi: 10.3354/meps061061

Hargrave, B. T., Duplisea, D. E., Pfeiffer, E., and Wildish, D. J. (1993). Seasonal changes in benthic fluxes of dissolved oxygen and ammonium associated with marine cultured Atlantic salmon. Mar. Ecol. Prog. Ser. 96, 149-157.

Hargrave, B. T., Phillips, T. A., Doucette, L. I., White, M. J., Milligan, T. G., Wildish, D. J., et al. (1997). "Assessing benthic impacts of organic enrichment from marine aquaculture," in The Interactions between Sediments and Water, eds R. D. Evans, J. Wisniewski, and J. R. Wisniewski, (Dordrecht: Springer), 641-650. doi: 10.1007/bf02406903

Holmer, M., and Kristensen, E. (1992). Impact of marine fish cage farming on metabolism and sulphate reduction of underlying sediments. Mar. Ecol. Prog. Ser. 80, 191-201. doi: 10.3354/meps080191

Holmer, M., Marbà, N., Díaz-Almela, E., Duarte, C. M., Tsapakis, M., and Danovaro, R. (2007). Sedimentation of organic matter from fish farms in oligotrophic Mediterranean assessed through bulk and stable isotope ( $\delta 13 \mathrm{C}$ and $\delta 15 N$ ) analyses. Aquaculture 262, 268-280. doi: 10.1016/j.aquaculture.2006. 09.033

IUCN, (2012). Marine Mammals and Sea Turtles of the Mediterranean and Black Seas. Gland: IUCN, 32.

Karakassis, I. (2001). "Ecological effects of fish farming in the Mediterranean," in Environmental Impact Assessment of Mediterranean Aquaculture Farms, eds A. Uriarte, and B. Basurco, (Zaragoza: CIHEAM), 15-22.

Karakassis, I. (2007). "Effects of aquaculture on Mediterranean marine ecosystems: findings of recent EU-funded projects and ongoing research activities," in Proceedings of the CIESM, 2007 Ciesm Workshop Monographs on Impact of Mariculture on Coastal Ecosystems, Lisboa, 29-34.

Karakassis, I., Hatziyanni, E., Tsapakis, M., and Plaiti, W. (1999). Benthic recovery following cessation of fish farming: a series of successes and catastrophes. Mar. Ecol. Prog. Ser. 184, 205-218. doi: 10.3354/meps 184205

Karakassis, I., Pitta, P., and Krom, M. D. (2005). Contribution of fish farming to the nutrient loading of the Mediterranean. Sci. Mar. 69, 313-321. doi: 10.3989/scimar.2005.69n2313

Karakassis, I., Tsapakis, M., Hatziyanni, E., Papadopoulou, K. N., and Plaiti, W. (2000). Impact of cage farming of fish on the seabed in three Mediterranean coastal areas. ICES J. Mar. Sci. 57, 1462-1471. doi: 10.1006/jmsc.2000.0925

Karakassis, I., Tsapakis, M., Hatziyanni, E., and Pitta, P. (2001). Diel variation of nutrients and chlorophyll in sea bream and sea bass cages in the Mediterranean. Fresen. Environ. Bull. 10, 278-283.

Karakassis, I., Tsapakis, M., Smith, C. J., and Rumohr, H. (2002). Fish farming impacts in the Mediterranean studied through sediment profiling imagery. Mar. Ecol. Prog. Ser. 227, 125-133. doi: 10.3354/meps 227125

Katavić, I. (2005). Strateške smjernice za razvitak hrvatske marikulture. Naše More $51,6-11$.

Katavić, I. (2017). "Challenges facing marine aquaculture in the EUMediterranean," in Trends in Fisheries and Aquatic Animal Health, ed. B. Panagiotis, (Sharjah: Bentham Science Publishers), 42-84. doi: $10.2174 / 9781681085807117010006$ 
Katavić, I., and Antolić, B. (1999). On the impact of a sea bass (Dicentarchus labrax L.) cage farm on water quality and macrobenthic communities. Acta Adriat. 40, 19-32.

Katavić, I., and Dadić, V. (2000). Environmental consideration of mariculture: a case from Croatia. Period. Boil. 102, 23-30.

Katavić, I., Mladineo, N., Mladineo, M., Beg Paklar, G., and Lonćar, G. (2017). GIS-based Multi-Criteria Analysis for Mariculture Site Selection. (Dubrovnik: Aquaculture Europe), 571-572.

Katavić, I., and Tičina, V. (2005). "Fishing and farming of the northern bluefin tuna (Thunnus thynnus L.) in the Adriatic Sea," in Interactions between Aquaculture and Capture Fisheries: A Methodological Perspective. GFCM, Studies and Reviews No.78, eds S. Cataudella, F. Massa, and D. Crosetti, (Rome: FAO), 181-188.

Katavić, I., Tičina, V., and Franičević, V. (2003). "Bluefin tuna (Thunnus thynnus L.) farming on the Croatian coast of the Adriatic Sea: present stage and future plans," in Domestication of the Bluefin tuna Thunnus Thynnus Thynnus. Cahiers Options Mediterranéennes, Vol. 60, eds C. R. Bridges, H. Gordin, and A. García (Zaragoza: CIHEAM), 101-106.

Keil, R. G., Montlucon, D. B., Prahl, F. G., and Hedges, J. I. (1994). Sorptive preservation of labile organic matter in marine sediments. Nature 370, 549-552. doi: $10.1038 / 370549 \mathrm{a} 0$

Kovać, N., Cermelj, B., Vrišer, B., and Lojen, S. (2004). The Influence of Fish Farming on Coastal Marine Sediment in Slovenia UNEP/MAP Mariculture in the Mediterranean (Piran Bay northern Adriatic) - Summary: Case Study. UNEP/MAP Technical Report Series, 140. Athens: UNEP/MAP.

Kovać, N., Vrišer, B., and ćrmelj, B. (2001). Impacts of net cage fish farm on sedimentary biogeochemical and meiofaunal properties of the Gulf of Trieste. Ann. Ser. Hist. Nat. 11, 65-74.

Krom, M. D., Herut, B., and Mantoura, R. F. C. (2004). Nutrient budget for the Eastern Mediterranean. Implications for phosphorous limitation. Limnol. Oceanogr. 49, 1582-1592. doi: 10.4319/lo.2004.49.5.1582

Krom, M. D., Kress, N., Brenner, S., and Gordon, L. I. (1991). Phosphorus limitation of primary productivity in the eastern Mediterranean Sea. Limnol. Oceanogr. 36, 424-432. doi: 10.4319/lo.1991.36.3.0424

Kušpilić, G., Tičina, V., Matijević, S., Skejić, S., Antolić, B., Grubelić, I., et al. (2007). "Impact of fish farming on marine ecosystems - Croatian experiences," in Proceedings of the CIESM, 2007 Impact of Mariculture on Coastal Ecosystems, Lisboa, 29-34.

Kutti, T., Hansen, P. K., Ervik, A., Hosaeter, T., and Johanessen, P. (2007). Effects of organic effluent from a salmon farm on a fjord system. II Temporal and spatial patterns in infauna community composition. Aquaculture 262, 355-366. doi: 10.1016/j.aquaculture.2006.10.008

La Rosa, T., Mirto, S., Danovaro, R., and Mazzola, A. (2001). Differential responses of benthic microbes and meiofauna to fish farm disturbance in coastal sediments. Environ. Pollut. 112, 427-434. doi: 10.1016/s0269-7491(00)00141-x

La Rosa, T., Mirto, S., Favarolo, E., Savona, B., Sara, G., Danovaro, R., et al. (2002). Impact on the water column biogeochemistry of a Mediterranean mussel and fish farm. Water Res. 36, 713-721. doi: 10.1016/s0043-1354(01)00274-3

Machias, A., Karakassis, I., Giannoulaki, M., Papadopoulou, K. N., Smith, C. J., and Somarakis, S. (2005). The response of demersal fish communities to the presence of fish farms. Mar. Ecol. Prog. Ser. 288, 241-250. doi: 10.3354/ meps 288241

Machias, A., Karakassis, I., Labropoulou, M., Somarakis, S., Papadopoulou, K. N., and Papaconstantinou, C. (2004). Changes in wild fish assemblages after the establishment of a fish farming zone in an oligotrophic marine ecosystem. Estuar. Coast. Shelf Sci. 60, 771-779. doi: 10.1016/j.ecss.2004.03.014

Mantovani, S., Castaldelli, G., Rossi, R., and Fano, E. A. (2006). The infaunal community in experimentally seeded low and high density Manila clam (Tapes philippinarum) beds in a Po River Delta lagoon, Italy. ICES J. Mar. Sci 63, 860-866. doi: 10.1016/j.icesjms.2006.02.004

Matijević, S., Bilić, J., Ribićić, D., and Dunatov, J. (2012). Distribution of phosphorus species in below-cage sediments at the tuna farms in the middle Adriatic Sea (Croatia). Acta Adriat. 53, 399-412.

Matijević, S., Kušpilić, G., and Barić, A. (2006). Impact of a fish farm on physical and chemical properties of sediment and water column in the middle Adriatic Sea. Fresen. Environ. Bull. 15, 1058-1063.

Matijević, S., Kušpilić, G., Kljaković-Gašpić, Z., and Bogner, D. (2008). Impact of fish farming on the distribution of phosphorus in sediments in the middle
Adriatic area. Mar. Pollut. Bull. 56, 535-548. doi: 10.1016/j.marpolbul.2007. 11.017

Matijević, S., Kušpilić, G., Morović, M., Grbec, B., Bogner, D., Skejić, S., et al. (2009). Physical and chemical properties of the water column and sediments at sea bass/sea bream farm in the middle Adriatic (Maslinova Bay). Acta Adriat. 50, 59-76.

Mazzola, A., Mirto, S., and Danovaro, R. (1999). Initial fish-farm impact on meiofaunal assemblages in coastal sediments of the western Mediterranean. Mar. Pollut. Bull. 38, 1126-1133. doi: 10.1016/s0025-326x(99)00142-3

Mirto, S., La Rossa, T., Gambi, C., Danovaro, R., and Mazzola, A. (2002). Nematode community response to fish farm impact in the Western Mediterranean. Environ. Pollut. 116, 203-214. doi: 10.1016/s0269-7491(01)00140-3

Miyake, P. M., De la Serna, J. M., Di Natale, A., Farrugia, A., Katavić, I., Miyabe, N., et al. (2003). General review of bluefin tuna farming in the Mediterranean Area. ICCAT Coll. Vol. Sci. Pap. 55, 114-124.

Neori, A., Chopin, T., Troell, M., Buschmann, A. H., Kraemer, G. P., Halling, C., et al. (2004). Integrated aquaculture: rationale, evolution and state of the art emphasizing seaweed biofiltration in modern mariculture. Aquaculture 231, 361-391. doi: 10.1016/j.aquaculture.2003.11.015

Nickell, L. A., Black, K. D., Hughes, D. J., Overnell, J., Brand, T., Nickell, T. D., et al. (2003). Bioturbation, sediment fluxes and benthic community structure around a salmon cage farm in Loch Creran, Scotland. . J. Exp. Mar. Biol. Ecol. 285-286, 221-233. doi: 10.1016/s0022-0981(02)00529-4

Pawar, V., Matsuda, O., Yamamoto, T., Hashimoto, T., and Rajendran, N. (2001). Spatial and temporal variations of sediment quality in and around fish cage farms: a case study of aquaculture in the Seto Inland Sea, Japan. Fish. Sci. 67, 619-627. doi: 10.1046/j.1444-2906.2001.00298.x

Pillay, T. W. R. (2004). Aquaculture and the Environment. Oxford: Blackwell Publishing Ltd.

Pitta, P., Apostolaki, E. T., Giannoulaki, M., and Karakassis, I. (2005). Mesoscale changes in the water column in response to fish farming zones in three coastal areas in the Eastern Mediterranean Sea. Estuar. Coast. Shelf Sci. 65, 501-512. doi: 10.1016/j.ecss.2005.06.021

Pitta, P., Karakassis, I., Tsapakis, M., and Živanović, S. (1999). Natural versus mariculture induced variability in nutrients and plankton in the Eastern Mediterranean. Hydrobiologia 391, 181-194.

Porello, S., Tomassetti, P., Manzueto, L., Finoia, M. G., Persia, E., Mercatali, I., et al. (2005). The influence of marine cages on the sediment chemistry in the Western Mediterranean Sea. Aquaculture 249, 145-158. doi: 10.1016/j.aquaculture.2005. 02.042

Ruiz, J. M., Pérez, M., and Romero, J. (2001). Effects of fish farm loadings on seagrass (Posidonia oceanica) distribution, growth and photosynthesis. Mar. Pollut. Bull. 42, 749-760. doi: 10.1016/s0025-326x(00)00215-0

Sánchez-Jerez, P., Bayle-Sempere, J., Fernández-Jover, D., Valle, C., and Dempster, T. (2007). "Ecological relationship between wild fish populations and Mediterranean aquaculture in floating fish cages," in Proceedings of the CIESM Workshop Monographs on Impact of Mariculture on Coastal Ecosystems, Lisboa, 77-80.

Sanz-Lázaro, C., and Marín, A. (2008). "Assessment of finfish aquaculture impact on the benthic communities in the Mediterranean Sea," in Dynamic Biochemistry, Process Biotechnology and Molecular Biology 2, ed. R. Russo, (Ikenobe: Global Science Books Ltd), 21-32.

Sarà, G., Scilipoti, D., Mazzola, A., and Modica, A. (2004). Effects of fish farming waste to sedimentary and particulate organic matter in a southern Mediterranean area (Gulf of Castellammare, Sicily): a multiple stable isotope study $(\delta 13 \mathrm{C}$ and $\delta 15 \mathrm{~N})$. Aquaculture 234, 199-213. doi: 10.1016/j.aquaculture. 2003.11.020

Šegvić-Bubić, T., Grubišić, L., Karaman, N., Tičina, V., and Katavić, I. (2011a). Damages on mussel farms incurred by wild gilthead seabream Sparus aurata - self service on the ropes. Aquaculture 319, 497-504.

Šegvić-Bubić, T., Grubišić, L., Trumbić, Ž, Stanić, R., Ljubković, J., Maršić-Lućić, J., et al. (2017). Genetic characterization of wild and farmed European seabass in the Adriatic Sea: assessment of farmed escapees using a Bayesian approach. ICES J. Mar. Sci. 74, 369-378. doi: 10.1093/icesjms/fsw155

Šegvić-Bubić, T., Grubišić, L., Tičina, V., and Katavić, I. (2011b). Temporal and spatial variability of pelagic wild fish assemblages around Atlantic bluefin tuna Thunnus thynnus farms in the eastern Adriatic Sea. J. Fish Biol. 78, 78-97. doi: $10.1111 /$ j.1095-8649.2010.02837 
Silvert, W. (1992). Assessing environmental impact of finfish aquaculture in marine waters. Aquaculture 107, 69-79.

Skejić, S., Marasović, I., Vidjak, O., Kušpilić, G., Ninćević Gladan, Ž., Šestanović, S., et al. (2011). Effects of cage fish farming on phytoplankton community structure, biomass and primary production in an aquaculture area in the middle Adriatic Sea. Aquacul. Res 42, 1393-1405. doi: 10.1111/j.1365-2109. 2010.02733.x

Somarakis, S., Pavlidis, M., Saapoglou, C., Tsigenopoulos, C. S., and Dempster, T. (2013). Evidence for escape through spawning in large gilthead sea bream Sparus aurata reared in commercial sea-cages. Aquac. Environ. Interact. 3, 135-152. doi: 10.3354/aei00057

Staglićić, N., Šegvić-Bubić, T., Talijanćić, I., Žužul, I., Ugarković, P., Tičina, V., et al. (2017). Ecological role of bluefin tuna (Thunnus thynnus) fish farms for associated wild fish assemblages in the Mediterranean Sea. Mar. Environ. Res. 132, 79-93. doi: 10.1016/j.marenvres.2017.10.015

Tudela, S. (2004). Ecosystem effects of fishing in the Mediterranean: An analysis of the major threats of fishing gear and practices to biodiversity and marine habitats. General Fisheries Commission for the Mediterranean (FAO). Stud. Rev. 74:58.

Tuya, F., Sánchez-Jerez, P., Dempster, T., Boyra, A., and Haroun, R. (2006). Changes in demersal wild fish aggregations beneath a sea-cage fish farm after the cessation of farming. J. Fish. Biol. 69, 682-697. doi: 10.1111/j.1095-8649. 2006.01139.x

Valdemarsen, T., Kristensen, E., and Holmer, M. (2009). Metabolic threshold and sulfide-buffering in diffusion controlled marine sediments impacted by continuous organic enrichment. Biogeochem 95, 335-353. doi: 10.1007/s10533009-9340-x

Valle, C., Bayle-Sempere, J. T., Dempster, T., Sánchez-Jerez, P., and GimenezCasalduero, F. (2007). Temporal variability of wild fish assemblages associated with a sea-cage fish farm in the south-western Mediterranean Sea. Estuar. Coast. Shelf Sci. 72, 299-307. doi: 10.1016/j.ecss.2006. 10.019

Vita, R., Marin, A., Madrid, J. A., Jimenez-Brinquis, B., Cesar, A., and MarinGuirao, L. (2004). Effects of wild fishes on waste exportation from a Mediterranean fish farm. Mar. Ecol. Prog. Ser. 277, 253-261. doi: 10.3354/ meps 277253

Wu, R. S. (1995). The environmental impact of marine fish culture: towards a sustainable future. Mar. Pollut. Bull. 31, 159-166. doi: 10.1016/0025-326x(95) 00100-2

Zore-Armanda, M., Bone, M., Dadić, V., Morović, M., Ratković, D., Stojanoski, L. et al. (1991). Hydrographic properties of the Adriatic Sea in the period from 1971 through 1983. Acta Adriat. 32, 6-554.

Žužul, I., Šegvić-Bubić, T., Talijanćić, I., Džojić, T., Lepen Pleić, I., Beg Paklar, G., et al. (2019). Spatial connectivity pattern of expanding gilthead seabream populations and its interactions with aquaculture sites: a combined population genetic and physical modelling approach. Sci. Rep. 9:14718. doi: 10.1038/ s41598-019-51256-z

Conflict of Interest: The authors declare that the research was conducted in the absence of any commercial or financial relationships that could be construed as a potential conflict of interest.

Copyright (c) 2020 Tičina, Katavić and Grubišić. This is an open-access article distributed under the terms of the Creative Commons Attribution License (CC BY). The use, distribution or reproduction in other forums is permitted, provided the original author(s) and the copyright owner(s) are credited and that the original publication in this journal is cited, in accordance with accepted academic practice. No use, distribution or reproduction is permitted which does not comply with these terms. 